\title{
BMJ Open Vitamin D status in recently arrived immigrants from Africa and Asia: a cross-sectional study from Norway of children, adolescents and adults
}

\author{
Åse R Eggemoen, ${ }^{1,2}$ Kirsten V Knutsen, ${ }^{1}$ Ingvild Dalen, ${ }^{1}$ Anne K Jenum ${ }^{1,3}$
}

To cite: Eggemoen $\AA$ R, Knutsen KV, Dalen I, et al. Vitamin D status in recently arrived immigrants from Africa and Asia:

a cross-sectional study from Norway

of children, adolescents and adults. BMJ Open 2013;3:

e003293. doi:10.1136/

bmjopen-2013-003293

- Prepublication history for this paper is available online. To view these files please visit the journal online (http://dx.doi.org/10.1136/ bmjopen-2013-003293).

Received 23 May 2013 Revised 23 August 2013 Accepted 2 October 2013

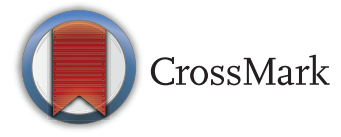

${ }^{1}$ Department of General Practice and Community Medicine, Institute of Health and Society, University of Oslo, Oslo, Norway ${ }^{2}$ Centre of Migrant Health, Health Agency, Oslo Municipality, Norway ${ }^{3}$ Oslo and Akershus College of Applied Sciences, Oslo, Norway

\section{Correspondence to} Åse R Eggemoen; a.r.eggemoen@medisin.uio.no

\section{ABSTRACT}

Objectives: To estimate the prevalence of vitamin $D$ deficiency $(25(\mathrm{OH}) \mathrm{D})<50 \mathrm{nmol} / \mathrm{L}$ among recently arrived immigrants from Africa and Asia in Oslo, and to explore $25(\mathrm{OH}) \mathrm{D}$ levels according to origin, gender and age.

Design: A cross-sectional study.

Setting: Primary healthcare unit in Oslo, Norway, offering family immigrants, asylum seekers, United Nations (UN) refugees or individuals granted asylum a free medical examination on arrival.

Participants: All individuals from African and Asian countries $(n=591)$ referred to the Centre of Migrant Health, Health Agency, Oslo, Norway in 2010, estimated to cover $60 \%$ of the targeted population.

Results: $25(\mathrm{OH}) \mathrm{D}<50 \mathrm{nmol} / \mathrm{L}$ was very prevalent in immigrants from the Middle East $(81 \%$ (95\% Cl $75.4 \%$ to $86.6 \%)$ ), South Sahara Africa ( $73 \%$ (Cl $67.5 \%$ to $78.5 \%)$ ) and South Asia (75\% (Cl 64.0\% to 86.0\%)), in contrast to East Asians (24\% (Cl $12.6 \%$ to $35.4 \%)$ ), $\mathrm{p}<0.001$ for differences. The prevalence of $25(\mathrm{OH})$ $\mathrm{D}<25 \mathrm{nmol} / \mathrm{L}$ was lower but followed the same pattern (Middle East: $38 \%$ (Cl 31.1\% to 45.0\%), South Sahara Africa: $24 \%$ (Cl 18.7\% to $29.3 \%$ ) and South Asia: $35 \%$ (Cl $22.9 \%$ to $47.1 \%$ ), although it was not observed in East Asians ( $p<0.001$ for differences)). The ethnic differences persisted after adjusting for the duration of residence, seasonality and residence status in multiple linear regression analyses. Female adolescents from South Asia, the Middle East and South Sahara Africa had the lowest levels of 25(OH)D. Further, countryspecific median levels of $25(\mathrm{OH}) \mathrm{D}$ were low (24-38 nmol/L) among groups from Somalia, Eritrea, Afghanistan and Iraq, the countries with the largest number of immigrants in our study.

Conclusions: The majority of recently settled immigrant groups from the Middle East, South Asia and Africa had $25(\mathrm{OH}) \mathrm{D}<50 \mathrm{nmol} / \mathrm{L}$, in contrast to East Asians. Female adolescents from these regions had the lowest levels of 25(OH)D.

\section{INTRODUCTION}

Vitamin D deficiency is common in immigrant groups from developing countries

\section{ARTICLE SUMMARY}

Strengths and weaknesses of this study

- The first study in Europe assessing 25(OH)D status of recently arrived immigrants from Africa and Asia.

- The study sample covers a large age span and both genders, and is considered more representative than clinical studies, often restricted to specific groups.

- The sample includes immigrants from Somalia, Eritrea, Afghanistan and Iraq, for whom data about 25(OH)D status have so far been sparse.

- Small number of participants for some countries of origin.

- Selection bias can not be ruled out as the study population could be less healthy than those not referred.

- The cross-sectional design implies that we can not make inferences about causality.

living in Western countries, including Northern Europe and the USA. ${ }^{1}$ Several studies have also found higher-than-expected rates of vitamin $\mathrm{D}$ deficiency in the general population in Western countries. ${ }^{2}$ Reports from across the world indicate that vitamin D deficiency is widespread and is re-emerging as a major health problem globally. ${ }^{2}$ The prevalence of vitamin D deficiency is high in low-income and middle-income countries despite the low latitude. ${ }^{3}$ Migration to higher latitudes seems to aggravate vitamin $\mathrm{D}$ deficiency, but vitamin D status also differs in the countries of origin and may be very low despite abundant sunlight. Several studies of the Middle Eastern and South Asian populations show low levels of vitamin D. ${ }^{24}$ Little is known about the vitamin D status in South Sahara Africa and Central and South America, but some studies indicate that vitamin D status seems to differ between countries. ${ }^{5}{ }^{6}$ Most studies from Asia report low levels of vitamin $\mathrm{D}$, except those from 
Japan and Malaysia. Studies from Oceania show inconsistent results despite a sunny climate. ${ }^{2}$ In Europe, vitamin D status varies with gradients from North to South and from West to East, ${ }^{7}$ although reports from Eastern Europe and Russia are few. Older age, female sex, higher latitude, winter season, darker skin pigmentation, less sunlight exposure, low socioeconomic status and dietary habits are the main factors significantly associated with low vitamin D levels. ${ }^{23}$

Vitamin D is essential for skeletal health and bone mineralisation and calcium homeostasis. ${ }^{8-10}$ Severe deficiency causes rickets in children and osteomalacia in adults. There is increasing interest in the association between vitamin $\mathrm{D}$ deficiency and other common diseases. ${ }^{11-14}$ Adequate vitamin D levels seem to protect against musculoskeletal disorders, infectious and autoimmune diseases, cardiovascular diseases, types 1 and 2 diabetes mellitus, several types of cancer, neurocognitive dysfunction and mental illness, as well as infertility and adverse pregnancy outcomes. Vitamin D deficiency is associated with all-cause mortality. ${ }^{15}$

Vitamin D is synthesised by the skin when exposed to direct sunlight, which may cover $80-90 \%$ of the needs, with the remaining being normally acquired through dietary sources. ${ }^{16}$ Vitamin D undergoes hydroxylation in the liver, resulting in the main circulating form 25-hydroxyvitamin D $(25(\mathrm{OH}) \mathrm{D})$, which is metabolised to the active form 1,25-dihydroxyvitamin $\mathrm{D}$, acting through vitamin D receptors found in many tissues. ${ }^{17} 18$ The serum level of $25(\mathrm{OH}) \mathrm{D}$ is the best indicator of an individual's vitamin D status. ${ }^{9}$

Vitamin D deficiency is far more prevalent among immigrants in Norway than among ethnic Norwegians, ${ }^{19-21}$ although few ethnic groups other than participants from Pakistan, Iran, Turkey, Sri Lanka and Vietnam have been studied. ${ }^{22-25}$ Today, the highest number of immigrants from Africa and Asia are from Somalia, Afghanistan, Eritrea, Pakistan and Iraq. ${ }^{26}$

The objectives of the present study were to estimate the prevalence of vitamin D deficiency among recently arrived immigrants from Africa and Asia to Oslo, and to explore vitamin D levels according to origin, gender and age.

\section{MATERIAL AND METHODS}

Design, setting and study population

This is a cross-sectional study of all new immigrants referred to the Centre of Migrant Health, Health Agency, Oslo municipality, the capital of Norway, situated at $60^{\circ} \mathrm{N}$, in 2010 . Individuals with missing values of $25(\mathrm{OH}) \mathrm{D}$ were excluded. The background population covered by this study is restricted to immigrants in the municipality of Oslo. The Centre offers a free medical examination for immigrants arriving as family immigrants, asylum seekers, unaccompanied minor asylum seekers, persons granted asylum or residence on humanitarian grounds, United Nations (UN) refugees and other legal residence permits (au pairs), while other working immigrants are expected to use standard healthcare services. Individuals are referred from Child Health Clinics, school nurses, the Section for Prevention of Tuberculosis at Oslo University Hospital (obligatory screening of tuberculosis), asylum reception centres, the UN refugee reception centre and Norwegian courses for recently settled immigrants.

\section{Data collection and variables}

Demographic data registered in electronic medical records: age, gender, country of birth, residence status, duration of residence in Norway and results of blood tests from medical records were consecutively collected.

S-25-hydroxyvitamin D was analysed by competitive radioimmunoassay (RIA; Kit from DiaSorin, Stillwater, Minnesota, USA) at the Hormone Laboratory, Oslo University Hospital, Aker. According to the Hormone Laboratory, the intra-assay and interassay coefficients of variation were 6 and 13-16\%, respectively. Vitamin D deficiency was defined as $25(\mathrm{OH}) \mathrm{D}<50 \mathrm{nmol} / \mathrm{L},{ }^{1} 1319$ and severe vitamin $\mathrm{D}$ deficiency as $25(\mathrm{OH}) \mathrm{D}<25 \mathrm{nmol} / \mathrm{L}$.

Residence status was categorised as: (1) family immigrants, (2) asylum status, (3) other legal residence permits (mainly au pairs). Ethnic origin was defined by the participant's mother's country of birth and further categorised into the following regions: South Sahara Africa (primarily Somalia, Eritrea, Ethiopia, Ghana and Kenya), the Middle East including North Africa (primarily Afghanistan, Iraq, Palestine, Iran, Morocco and Chechnya), South Asia (primarily Pakistan, Sri Lanka and Nepal), East Asia (primarily Philippines, Thailand and Myanmar) and others (ethnic origin from Eastern Europe and Central and South America due to the small sample size). We also report data for countries with the largest number of individuals: Somalia, Afghanistan, Eritrea and Iraq.

According to the Norwegian Directorate of Immigration (UDI) and Statistics Norway (SSB), 990 non-Western immigrants settled in Oslo with legal residence permits in 2010; 34 were UN refugees, 881 were family immigrants or persons granted asylum or residence on humanitarian grounds. Furthermore, 75 asylum seekers lived in asylum reception centres in Oslo in 2010, giving an estimated source population of 990 individuals. A total of 618 persons had a health check-up at the Centre in 2010; 27 (4\%) individuals had no valid $25(\mathrm{OH}) \mathrm{D}$; blood test was not ordered in 16 who had recently drawn blood elsewhere; 7 did not take the recommended blood tests and for 4 the blood samples were not analysed. They represent both genders, all age groups and all regions, with no significant differences between groups ( $p>0.05$ for all), resulting in a study sample of 591 individuals. Based on data from the Norwegian Directorate of Immigration and Statistics Norway (SSB) stating that about 990 individuals settled in Oslo in 2010, we estimate that the study population covers $60 \%$ of the source population. Detailed information from the Norwegian Directorate of 
Immigration about family immigrants to Oslo in 2010 indicates that our sample covers about $85 \%$ of family immigrants from Somalia, Ethiopia and Eritrea and 68\% from Iraq, Iran, Morocco and Afghanistan.

As data were consecutively collected as part of routine care, the Regional Committee for Research Ethics in Norway considered the work a quality study not requiring formal approval. No person identifiable information was registered (anonymous data).

\section{Statistics}

Median values with the 25th and 75th centiles for skewed variables, mean values and SDs for normally distributed variables and proportions with different levels of $25(\mathrm{OH}) \mathrm{D}$ are reported. The Kruskal-Wallis test (nonnormally distributed continuous data) and Pearson's $\chi^{2}$ (categorical variables) were used for comparisons between groups. 25(OH)D levels were log transformed due to the skewed distributions. The results are backtransformed and presented as geometric means.

Multiple linear regression was performed to assess the relationship between demographic (independent variables) and the level of $25(\mathrm{OH}) \mathrm{D}$ (dependent variable). Owing to the non-linear relationships with the (log transformed) $25(\mathrm{OH}) \mathrm{D}$ levels, the variables age and duration of stay were categorised. The unadjusted model included the variables of interest: gender, age group and region of origin, as well as all two-way and three-way interactions. In the fully adjusted linear regression model, potential confounders (duration of residence in Norway, season of blood test and residence status) were additionally included with main effects and with two-way interactions with the variables of interest. Wald tests were performed to test for equality of coefficients, with Sidak adjustment of $p$ values.

The analyses were performed in SPSS V.18 and STATA V.12. Two-sided tests were used and a significance level of 0.05 was set.

\section{RESULTS}

A total of 591 participants from 51 different countries were examined in 2010 and had valid $25(\mathrm{OH}) \mathrm{D}$ values. Characteristics of the sample are given in table 1 . The mean age was 22.7 years (range $0-88$ ); $54.4 \%$ of the population were female, and the median time of stay in Norway was 4 months (table 1). The ethnic groups were similar with regard to gender, age, months living in Norway and residence status. Individuals were referred to the Centre from Section for Prevention of Tuberculosis at Oslo University Hospital $(n=118)$, Norwegian courses for recently settled immigrants $(\mathrm{n}=105)$, school nurses $(\mathrm{n}=101)$, Child Health Clinics $(\mathrm{n}=99)$, asylum reception centre $(n=48)$ and the UN refugee reception centre $(n=47)$.

Although the median $25(\mathrm{OH}) \mathrm{D}$ level was $37 \mathrm{nmol} / \mathrm{L}$, large differences between the ethnic groups were observed (lowest for the Middle East: $29 \mathrm{nmol} / \mathrm{L}$ and highest for East Asia: $62 \mathrm{nmol} / \mathrm{L}(\mathrm{p}<0.001$, table 1). The

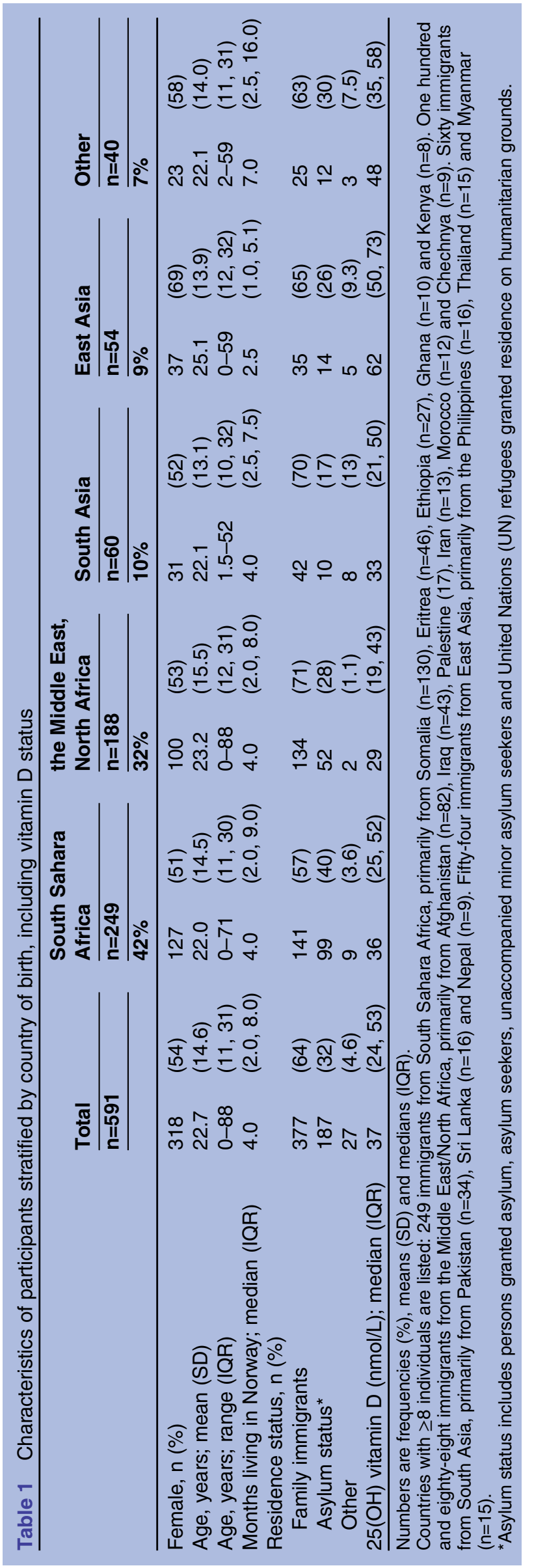



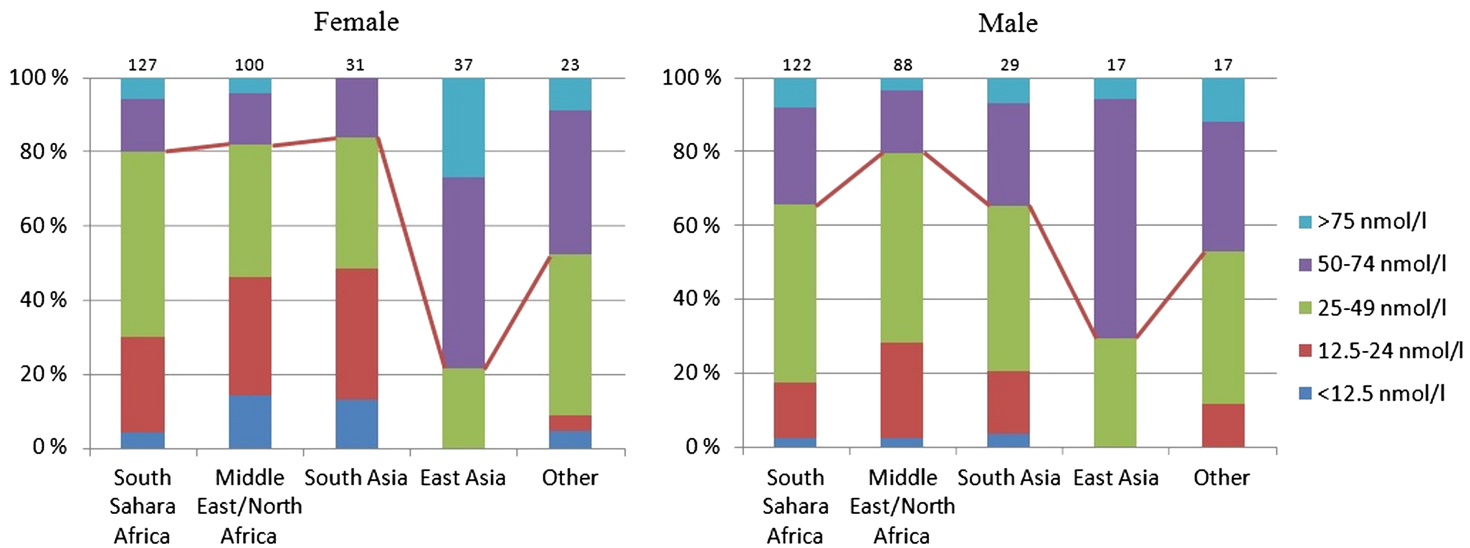

Figure 1 Proportion of participants (\%) in categories of serum 25(OH)D concentrations in females and males according to geographic origin.

prevalence of $25(\mathrm{OH}) \mathrm{D}$ deficiency differed among the ethnic groups (figure 1; for $25(\mathrm{OH}) \mathrm{D}<50 \mathrm{nmol} / \mathrm{L}$ 一the Middle East: $81 \%$ (95\% CI $75.4 \%$ to $86.6 \%$ ), South Asia: $75 \%$ (CI $64.0 \%$ to $86.0 \%$ ), South Sahara Africa: $73 \%$ (CI $67.5 \%$ to $78.5 \%$ ), East Asia: $24 \%$ (CI $12.6 \%$ to $35.6 \%), \mathrm{p}<0.001$ for differences, and for severe deficiency $25(\mathrm{OH}) \mathrm{D}<25 \mathrm{nmol} / \mathrm{L}$ - the Middle East: $38 \%$ (CI $31.1 \%$ to $45.0 \%$ ), South Asia: $35 \%$ (CI $22.9 \%$ to $47.1 \%$ ), South Sahara Africa: $24 \%$ (CI $18.7 \%$ to $29.3 \%$ ), while no East Asians had levels below this value, $\mathrm{p}<0.001$ for differences). Geometric means of $25(\mathrm{OH}) \mathrm{D}$ according to age, duration of residence in Norway, residence status and season for both genders are given in table 2. The overall level was significantly lower for female than male participants $(\mathrm{p}<0.001)$. The lowest level was found in female adolescents (age 10-17 years).

Estimated 25(OH)D geometric mean levels for three age groups and both genders (unadjusted model, table 3) also differed between the ethnic groups. After adjusting for potential confounders (duration of residence, residence status and season, adjusted linear regression model, table 3), the ethnic differences

Table 2 Crude geometric mean $(95 \% \mathrm{Cl})$ vitamin $\mathrm{D}(25(\mathrm{OH}) \mathrm{D}$ in $\mathrm{nmol} / \mathrm{L})$ levels according to gender, age, duration of residence in Norway, residence status and season for 591 participants with valid vitamin D

\begin{tabular}{|c|c|c|c|c|c|c|}
\hline & \multicolumn{2}{|c|}{$\frac{\text { Total }}{n=591}$} & \multicolumn{2}{|c|}{$\begin{array}{l}\text { Female } \\
\mathrm{n}=318 \\
\end{array}$} & \multicolumn{2}{|c|}{$\frac{\text { Male }}{n=273}$} \\
\hline & $\mathbf{n}$ & $\begin{array}{l}\text { Geometric mean } \\
(95 \% \mathrm{Cl})\end{array}$ & $\mathbf{n}$ & $\begin{array}{l}\text { Geometric mean } \\
(95 \% \mathrm{Cl})\end{array}$ & $(1-2$ & $\begin{array}{l}\text { Geometric mean } \\
(95 \% \mathrm{Cl})\end{array}$ \\
\hline Overall & & 35 (33 to 36$)$ & & 32 (30 to 35$)$ & & $38(36 \text { to } 40)^{\star \star \star}$ \\
\hline \multicolumn{7}{|l|}{ Age (years) } \\
\hline$<10$ & 116 & 43 (40 to 47$)$ & 66 & 40 (35 to 45$)$ & 50 & $48(43 \text { to } 54)^{\star}$ \\
\hline $10-17$ & 141 & 30 (28 to 33$) \dagger † \dagger$ & 52 & 24 (21 to 29$) \dagger \dagger \dagger$ & 89 & $34(31 \text { to } 38)^{\star \star \star}+\dagger$ \\
\hline $18-29$ & 169 & 31 (29 to 34)††† & 106 & 30 (27 to 34$) \dagger \dagger$ & 63 & 34 (30 to 39)†† \\
\hline $30-40$ & 107 & 36 (32 to 39) $†$ & 63 & 33 (29 to 38$)$ & 44 & 39 (33 to 46$)$ \\
\hline$>40$ & 58 & 40 (36 to 47$)$ & 31 & 42 (34 to 52 ) & 27 & 39 (31 to 49$)$ \\
\hline \multicolumn{7}{|c|}{ Duration of residence in Norway (months) } \\
\hline$\leq 2$ months & 177 & 38 (35 to 41$)$ & 98 & 35 (31 to 40$)$ & 79 & 42 (37 to 48$)$ \\
\hline$>2-6$ months & 230 & $33(31$ to 36$) \dagger$ & 143 & 30 (28 to 33 ) & 87 & 38 (34 to 43$)$ \\
\hline$>6$ months & 184 & 34 (31 to 36$)$ & 77 & 33 (29 to 37$)$ & 107 & 34 (32 to 38$) \dagger$ \\
\hline \multicolumn{7}{|l|}{ Residence status } \\
\hline Family immigrants & 377 & 36 (34 to 38$)$ & 225 & 32 (30 to 35$)$ & 152 & 41 (38 to 45$) \dagger \dagger$ \\
\hline Asylum status & 187 & 32 (30 to 35$)$ & 76 & 30 (27 to 35$)$ & 111 & 33 (30 to 37$)$ \\
\hline Other & 27 & 41 (34 to 49 ) & 17 & 41 (32 to 53$)$ & 10 & 40 (29 to 56$)$ \\
\hline \multicolumn{7}{|l|}{ Season } \\
\hline Winter (December-May) & 331 & 33 (31 to 35$)$ & 183 & 31 (28 to 34$)$ & 148 & 36 (33 to 39$)$ \\
\hline Summer (June-November) & 260 & 37 (35 to 39$) \dagger$ & 135 & 34 (31 to 38$)$ & 125 & 40 (37 to 44$)$ \\
\hline
\end{tabular}


Table 3 Crude and adjusted estimated Vitamin $\mathrm{D}[25(\mathrm{OH}) \mathrm{D}$ in $\mathrm{nmol} / \mathrm{L}]$ levels from a different geographic origin according to gender and age

\begin{tabular}{|c|c|c|c|c|c|c|}
\hline & \multicolumn{3}{|c|}{ Female } & \multicolumn{3}{|c|}{ Male } \\
\hline & $\mathbf{n}$ & $\begin{array}{l}\text { Unadjusted } \\
\text { Geometric mean } \\
(95 \% \mathrm{Cl})\end{array}$ & $\begin{array}{l}\text { Adjusted }{ }^{\star} \\
\text { Geometric mean } \\
(95 \% \mathrm{Cl})\end{array}$ & $\mathbf{n}$ & $\begin{array}{l}\text { Unadjusted } \\
\text { Geometric mean } \\
(95 \% \mathrm{Cl})\end{array}$ & $\begin{array}{l}\text { Adjusted }^{*} \\
\text { Geometric mean } \\
(95 \% \mathrm{Cl})\end{array}$ \\
\hline \multicolumn{7}{|l|}{ Age group $<10$ years } \\
\hline South Sahara Africa & 28 & 42 (35 to 51$)$ & 44 (36 to 54$)$ & 24 & 50 (41 to 61$)$ & 51 (41 to 63 ) \\
\hline The Middle East, North Africa & 20 & 33 (27 to 41$)$ & 39 (31 to 49$)$ & 14 & 45 (34 to 58$)$ & 49 (38 to 64$)$ \\
\hline South Asia & 7 & 31 (21 to 44$)$ & 31 (21 to 46$)$ & 5 & 44 (28 to 67$)$ & 37 (24 to 57$)$ \\
\hline East Asia & 6 & 60 (40 to 89$)$ & 60 (41 to 88$)$ & 4 & $62(38$ to 101$)$ & 61 (37 to 99 ) \\
\hline Other & 5 & 50 (33 to 78$)$ & 47 (30 to 75$)$ & 3 & $44(25$ to 78$)$ & 35 (20 to 62$)$ \\
\hline \multicolumn{7}{|l|}{ Age group $10-17$ years } \\
\hline South Sahara Africa & 22 & 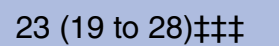 & 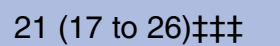 & 41 & 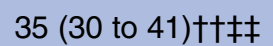 & 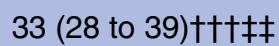 \\
\hline The Middle East, North Africa & 13 & 21 (16 to 27$) \ddagger$ & 21 (15 to 27$) \ddagger \ddagger \ddagger$ & 31 & 31 (26 to 37$) \dagger \ddagger$ & 30 (25 to 36$) \dagger \ddagger \ddagger$ \\
\hline South Asia & 7 & 15 (10 to 22$) \ddagger$ & $16(10$ to 25$) \ddagger$ & 8 & $31(22$ to 44$) \dagger \dagger$ & $31(22$ to 44$) \dagger$ \\
\hline East Asia & 4 & 59 (37 to 96$) \S \S$ & 54 (32 to 91$) \S \S$ & 4 & 52 (32 to 85$)$ & 41 (25 to 69$)$ \\
\hline Other & 6 & 40 (27 to 59$)$ & $37(25$ to 54$)$ & 5 & 45 (29 to 77$)$ & 41 (25 to 66$)$ \\
\hline \multicolumn{7}{|l|}{ Age group $\geq 18$ years } \\
\hline South Sahara Africa & 77 & 31 (28 to 35$) \ddagger \ddagger$ & 33 (30 to 37) & 57 & 36 (32 to 41$) \ddagger$ & 44 (38 to 51$) \dagger \dagger$ \\
\hline The Middle East, North Africa & 67 & $25(22$ to 28$)$ & 27 (24 to 31$) \ddagger \ddagger$ & 43 & 31 (27 to 36$) \dagger \ddagger$ & 27 (23 to 33$) \ddagger \ddagger \S \S \S$ \\
\hline South Asia & 17 & 30 (24 to 38$)$ & 29 (23 to 37$)$ & 16 & 41 (32 to 52$)$ & 37 (29 to 47$)$ \\
\hline East Asia & 27 & 61 (51 to 74$) \S \S \S$ & 59 (48 to 72$) \S \S \S$ & 9 & 63 (45 to 86$) \S \S$ & 58 (42 to 80$)$ \\
\hline Other & 12 & $48(37$ to 64$) \S$ & 43 (32 to 57$)$ & 9 & 45 (32 to 62$)$ & 43 (31 to 60$)$ \\
\hline \multicolumn{7}{|c|}{ 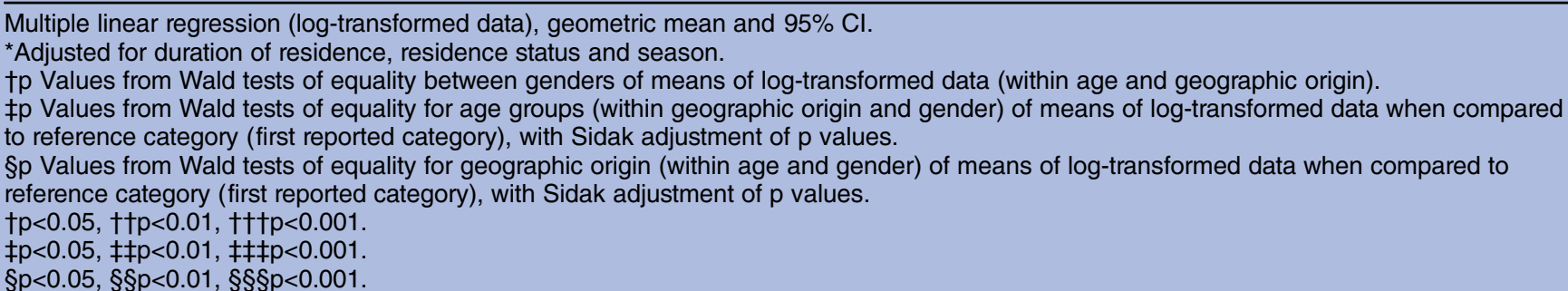 } \\
\hline
\end{tabular}

persisted. East Asians had the highest levels compared with the other groups. Geometric mean $25(\mathrm{OH}) \mathrm{D}$ values were particularly low with estimated values $<25 \mathrm{nmol} / \mathrm{L}$ among females (age 10-17 years) from Africa, the Middle East and South Asia.

$25(\mathrm{OH}) \mathrm{D}<25 \mathrm{nmol} / \mathrm{L}$ was prevalent among female adolescents; $58 \%$ in the $10-17$ years age group had 25 $(\mathrm{OH}) \mathrm{D}<25 \mathrm{nmol} / \mathrm{L}$, compared with $30 \%$ in the $>18$ years age group and $17 \%$ of children $<10$ years of age $(\mathrm{p}<0.001)$. Among males, $4 \%$ younger than 10 years of age, $23 \%$ of 10 -year olds to 17 -year olds and $24 \%$ of those older than 18 years of age had $25(\mathrm{OH}) \mathrm{D}$ $<25 \mathrm{nmol} / \mathrm{L}(\mathrm{p}=0.008)$.

Unadjusted median $25(\mathrm{OH}) \mathrm{D}$ values for countries with the largest number of participants are reported (130 from Somalia, 46 from Eritrea, 82 from Afghanistan and 43 from Iraq). Median 25(OH)D values were 38 and $28 \mathrm{nmol} / \mathrm{L}$ in Somali and Eritrean males and 30 and $28 \mathrm{nmol} / \mathrm{L}$ in Somali and Eritrean females, respectively; these values were lower than for the rest of the South Sahara African region $(\mathrm{p}<0.001)$. The corresponding median values in Afghani and Iraqi males were 27 and $32 \mathrm{nmol} / \mathrm{L}$, and in Afghani and Iraqi females 26 and $24 \mathrm{nmol} / \mathrm{L}$, which for both genders was lower than for the rest of the Middle Eastern region $(\mathrm{p}<0.001) .25(\mathrm{OH})$ $\mathrm{D}<25 \mathrm{nmol} / \mathrm{L}$ was prevalent (figure 2), but mostly in females; also in females, $56 \%$ of Iraqi, $48 \%$ of Eritrean and Afghani and $36 \%$ of Somalis had $25(\mathrm{OH}) \mathrm{D}$ $<25 \mathrm{nmol} / \mathrm{L}$. In males, $39 \%$ of Afghani, $33 \%$ of Iraqi, $32 \%$ of Eritrean and $16 \%$ of Somalis had $25(\mathrm{OH}) \mathrm{D}$ $<25 \mathrm{nmol} / \mathrm{L}$.

\section{DISCUSSION}

To our knowledge, this is the first study in Europe to estimate $25(\mathrm{OH}) \mathrm{D}$ status and prevalence of $25(\mathrm{OH}) \mathrm{D}$ deficiency in recently arrived immigrants from Africa and Asia, covering children, adolescents and adults of both genders. Among immigrants from South Sahara Africa, the Middle East and South Asia, nearly $80 \%$ had $25(\mathrm{OH}) \mathrm{D}<50 \mathrm{nmol} / \mathrm{L}$. From these regions, approximately one-third had $25(\mathrm{OH}) \mathrm{D}<25 \mathrm{nmol} / \mathrm{L}$. In contrast, in the East Asian population, one-fourth had $25(\mathrm{OH}) \mathrm{D}$ levels $<50 \mathrm{nmol} / \mathrm{L}$ and none had $25(\mathrm{OH}) \mathrm{D}<25 \mathrm{nmol} / \mathrm{L}$. $25(\mathrm{OH}) \mathrm{D}$ levels also show striking differences according to gender and age, with female adolescents from South Sahara Africa, the Middle East and South Asia having an alarmingly low geometric mean value after adjusting for 

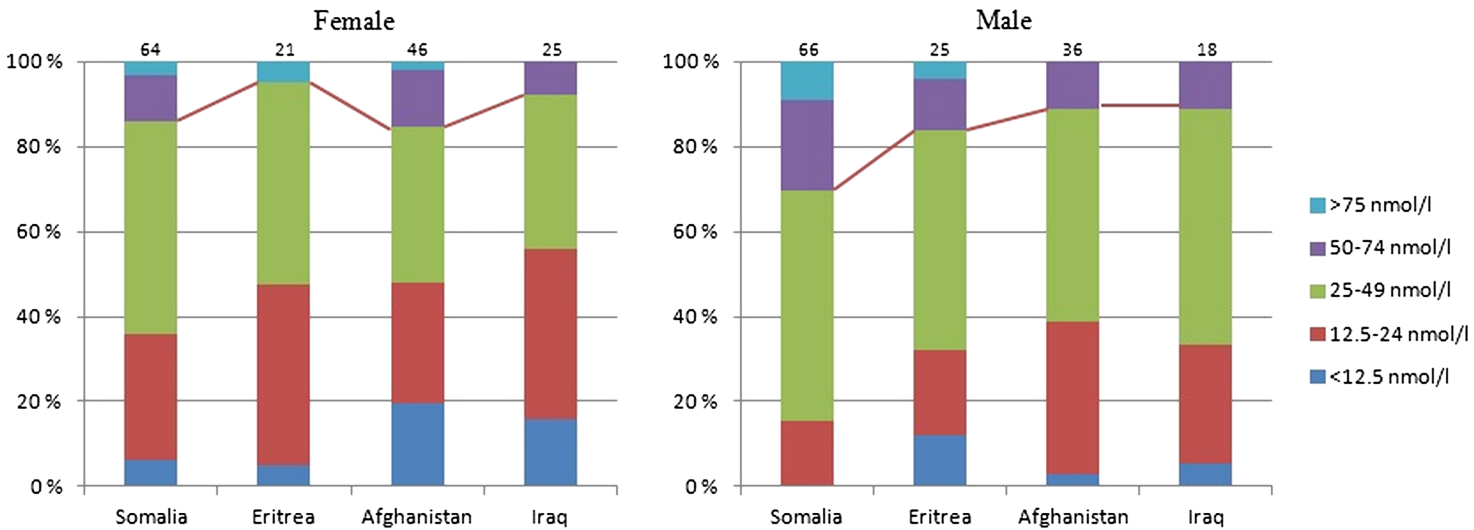

Figure 2 Proportion of participants (\%) in categories of serum $25(\mathrm{OH}) \mathrm{D}$ concentrations in females and males according to origin from Somalia, Eritrea, Afghanistan or Iraq.

confounders (duration of residence, residence status and season). They also had the highest risk of $25(\mathrm{OH}) \mathrm{D}$ $<25 \mathrm{nmol} / \mathrm{L}$, which is closely linked with adverse clinical outcomes. ${ }^{8-10}$ Furthermore, the median $25(\mathrm{OH}) \mathrm{D}$ levels are low $(24-38 \mathrm{nmol} / \mathrm{L})$ among immigrants from Somalia, Eritrea, Afghanistan and Iraq, the countries with the largest numbers in our study, and $25(\mathrm{OH}) \mathrm{D}$ $<25 \mathrm{nmol} / \mathrm{L}$ is prevalent in these groups. Hence, the majority coming from Africa, the Middle East and South Asia had $25(\mathrm{OH}) \mathrm{D}<50 \mathrm{nmol} / \mathrm{L}$ on arrival in Norway.

The study includes consecutively registered $25(\mathrm{OH}) \mathrm{D}$ for $96 \%$ of all participants attending the Centre of Migrant Health in 2010, measured with standard methods at the same laboratory. Few values were missing, most likely at random. Those referred are mostly healthy individuals; the sample covers a large age span and should be more representative than clinical studies or studies restricted to specific age groups or clinical settings (like pregnant or postpartum women). Furthermore, although we do not have detailed information about the size of the source population, especially not about working immigrants with the largest groups coming from Eastern Europe in 2010, the study population mostly covers immigrants from countries with no/ few working immigrants. Another strength is that the sample includes groups from Somalia, Eritrea, Iraq and Afghanistan, where data about $25(\mathrm{OH}) \mathrm{D}$ status have been lacking. We have performed a sensitivity analysis for the groups from South Sahara Africa and the Middle East under the assumption that the proportion with 25 $(\mathrm{OH}) \mathrm{D}<50 \mathrm{nmol}$ among the $40 \%$ not referred was $25 \%$ lower than we reported. If so, the true prevalence in the total South Sahara Africa group would be $66 \%$, not $73 \%$ as reported. Similarly, the true prevalence in the Middle Eastern group would be $73 \%$, not $81 \%$. However, 25 $(\mathrm{OH}) \mathrm{D}<50 \mathrm{nmol} / \mathrm{L}$ would still be very prevalent. Data from The Norwegian Directorate of Immigration indicates that our sample covers about $85 \%$ of family immigrants from Somalia, Ethiopia and Eritrea and 68\% from Iraq, Iran, Morocco and Afghanistan. This lends support to the notion that the study population, especially the groups from South Sahara Africa and the Middle East, can be considered as representative of recently arrived immigrants from these regions. However, some weaknesses exist, related to the small numbers for some countries or regions, and missing information about other possible confounders, such as education. Furthermore, heterogeneity may exist within regions. Although available data indicate that the study population is fairly representative of family immigrants and asylum seekers, the main groups in our study, we cannot rule out selection bias; the study population could be less healthy than those not referred. We do not know the migration story in detail, such as the transit period and transit country, dietary habits or the degree of concealing clothing in females. Furthermore, those coming to Norway may be more healthy and not be representative of the majority in their home country, ${ }^{27} 28$ so the data cannot be generalised to represent their home countries, even though $25(\mathrm{OH}) \mathrm{D}$ status was assessed shortly after arrival for the majority. Lastly, as the study used a cross-sectional design to study $25(\mathrm{OH}) \mathrm{D}$ status in immigrants at arrival, we cannot make inferences about causal predictors for the observed $25(\mathrm{OH}) \mathrm{D}$ deficiency, or for $25(\mathrm{OH}) \mathrm{D}$ status in the immigrant populations in general, as such studies would necessitate a prospective design.

The problems involved when comparing studies are many; the methods of measuring $25(\mathrm{OH}) \mathrm{D}$ levels vary extensively and direct comparison of $25(\mathrm{OH}) \mathrm{D}$ levels between studies is not reliable unless the same assay is used or the assays are cross calibrated. ${ }^{29}{ }^{30}$ Different definitions of $25(\mathrm{OH}) \mathrm{D}$ deficiency are in use, and few studies use population-based samples. Our study is in accordance with several other population-based studies showing that $25(\mathrm{OH}) \mathrm{D}$ deficiency is prevalent globally. ${ }^{23}$ However, heterogeneity between regions exists. Only 24\% from East Asia, mainly those born in Thailand and the Philippines, had 25(OH)D deficiency in our study. The Oslo immigrant study, however, showed a high prevalence $(80-85 \%)$ of deficiency among adults from Vietnam. ${ }^{23}$ Until now, little is known about $25(\mathrm{OH}) \mathrm{D}$ 
status in most low-income countries. We found no studies of $25(\mathrm{OH}) \mathrm{D}$ status from Somalia, Eritrea and Iraq, a few studies from Pakistan ${ }^{31} 32$ and only one study from Afghanistan of children $<5$ years of age. ${ }^{33}$ Participants from Somalia, Eritrea, Afghanistan and Iraq are the largest groups in our study and are highly represented among the new immigrant groups in Europe. The higher age among females from these countries probably reflects the family reunion pattern, with more male than female family members already settled. So far, we know little about the health status of these groups. One study of Somali women living in Finland showed high prevalence $25(\mathrm{OH}) \mathrm{D}$ deficiency, in line with our results. ${ }^{34}$ A study of an immigrant and refugee population to the USA shows similar results of $25(\mathrm{OH}) \mathrm{D}$ deficiency among individuals from Ethiopia and Somalia, although the time since arrival in the USA was unknown. ${ }^{35}$ Accordingly, as $25(\mathrm{OH}) \mathrm{D}$ status in Somalia, Eritrea, Afghanistan and Iraq is largely unknown, our study adds important information and might give an indication of the situation in their countries of origin.

Although the clinical impact of moderate deficiency $(25(\mathrm{OH}) \mathrm{D} 25-50 \mathrm{nmol} / \mathrm{L})$ is not clear, there is no dispute that severe deficiency $(25(\mathrm{OH}) \mathrm{D}<25 \mathrm{nmol} / \mathrm{L})$ should be detected and treated to avoid adverse clinical outcomes for the individuals. ${ }^{16}$ Rickets was nearly eradicated in the Western world after vitamin D fortification of food. In Norway, the prevalent daily intake of fish oil during winter has contributed to a relatively low prevalence of $25(\mathrm{OH}) \mathrm{D}$ deficiency.

As a response to the increasing incidence of $25(\mathrm{OH}) \mathrm{D}$ deficiency globally, new reference values for vitamin D are recently published, ${ }^{9}{ }^{16}$ also reflected in new Norwegian recommendations which are underway. ${ }^{36}$ The high prevalence found in recently arrived groups from Africa, the Middle East and South Asia, especially in female adolescents, deserves clinical attention as well as awareness from public health authorities.

Identification and treatment of $25(\mathrm{OH}) \mathrm{D}$ deficiency could either be addressed with a high-risk approach, as a clinical health issue in primary healthcare, or primarily by a population-based approach recommending daily intake of vitamin D supplements or more sun exposure, taking into account the risk of skin cancer. The population-based approach is considered the most costeffective, taking into account the costs of consultations and blood test analyses, but a combined approach is probably necessary.

We still lack evidence of causal relation between vitamin $\mathrm{D}$ and cancer, diabetes, cardiovascular disease and autoimmune and infectious disease, but several ongoing randomised clinical trials address the relations between vitamin $\mathrm{D}$ and extraskeletal diseases.

\section{CONCLUSION}

Approximately $80 \%$ of recently arrived non-Western immigrants from Africa, the Middle East and South
Asia had $25(\mathrm{OH}) \mathrm{D}<50 \mathrm{nmol} / \mathrm{L}$ and one in three $25(\mathrm{OH}) \mathrm{D}<25 \mathrm{nmol} / \mathrm{L} . \quad 25(\mathrm{OH}) \mathrm{D}<50 \mathrm{nmol} / \mathrm{L}$ and $<25 \mathrm{nmol} / \mathrm{L}$ was most prevalent among women. Furthermore, this study provides country-specific data for recently settled immigrants from countries where data of $25(\mathrm{OH}) \mathrm{D}$ status are scarce, such as Somalia, Eritrea, Afghanistan and Iraq, and 25(OH)D $<25 \mathrm{nmol} / \mathrm{L}$ was found to be prevalent in these groups. Increased awareness of $25(\mathrm{OH}) \mathrm{D}<50 \mathrm{nmol} / \mathrm{L}$ among adolescents, especially females, seems warranted. The high prevalence of $25(\mathrm{OH}) \mathrm{D}<25 \mathrm{nmol} / \mathrm{L}$ is likely to have clinical implications for the growth of children and adolescents, for pregnant women and their offspring, and is important for public health authorities. Clinicians should probably measure $25(\mathrm{OH}) \mathrm{D}$ as a routine test in immigrants from Africa, the Middle East and South Asia.

Acknowledgements The authors would like to thank the Hormone Laboratory in Oslo University Hospital for analysis and interpretation of vitamin D in serum. They also thank Kåre Inge Birkeland, Faculty of Medicine, University of Oslo, for reading and commenting on the manuscript.

Contributors ÅRE initiated the study in close collaboration with AKJ and prepared the first version of the manuscript. KVK contributed to the discussion of the results. ÅRE and ID did all the statistical analyses. All authors have read the successive versions of the manuscript and approved the final version.

Funding This study was supported by a grant from the Norwegian Medical Association.

\section{Competing interests None.}

Provenance and peer review Not commissioned; externally peer reviewed.

Open Access This is an Open Access article distributed in accordance with the Creative Commons Attribution Non Commercial (CC BY-NC 3.0) license, which permits others to distribute, remix, adapt, build upon this work noncommercially, and license their derivative works on different terms, provided the original work is properly cited and the use is non-commercial. See: http:// creativecommons.org/licenses/by-nc/3.0/

\section{REFERENCES}

1. Holick MF. Vitamin D deficiency. N Engl J Med 2007;357:266-81.

2. Mithal A, Wahl DA, Bonjour JP, et al. Global vitamin D status and determinants of hypovitaminosis D. Osteoporos Int 2009;20:1807-20.

3. Arabi A, El RR, El-Hajj FG. Hypovitaminosis D in developing countries-prevalence, risk factors and outcomes. Nat Rev Endocrinol 2010;6:550-61.

4. Bener A, Al-Ali M, Hoffmann GF. Vitamin D deficiency in healthy children in a sunny country: associated factors. Int J Food Sci Nutr 2009;60(Suppl 5):60-70.

5. van der Meer IM, Middelkoop BJ, Boeke AJ, et al. Prevalence of vitamin D deficiency among Turkish, Moroccan, Indian and sub-Sahara African populations in Europe and their countries of origin: an overview. Osteoporos Int 2011;22:1009-21.

6. Thacher TD, Fischer PR, Strand MA, et al. Nutritional rickets around the world: causes and future directions. Ann Trop Paediatr 2006;26:1-16.

7. van Schoor NM, Lips P. Worldwide vitamin D status. Best Pract Res Clin Endocrinol Metab 2011;25:671-80.

8. Rosen CJ, Abrams SA, Aloia JF, et al. IOM committee members respond to Endocrine Society vitamin D guideline. J Clin Endocrinol Metab 2012;97:1146-52.

9. Ross A, Taylor C, Yaktine A, et al. Dietary reference intakes for calcium and vitamin D. Washington, DC: National Academy of Sciences, 2011.

10. Holick MF, Binkley NC, Bischoff-Ferrari HA, et al. Evaluation, treatment, and prevention of vitamin $D$ deficiency: an Endocrine 
Society Clinical Practice Guideline. J Clin Endocrinol Metab 2011;96:1911-30.

11. Holick MF. Vitamin D: important for prevention of osteoporosis, cardiovascular heart disease, type 1 diabetes, autoimmune diseases, and some cancers. South Med J 2005;98:1024-7.

12. Holick MF, Binkley NC, Bischoff-Ferrari HA, et al. Guidelines for preventing and treating vitamin $D$ deficiency and insufficiency revisited. J Clin Endocrinol Metab 2012;97:1153-8.

13. Bischoff-Ferrari HA, Giovannucci E, Willett WC, et al. Estimation of optimal serum concentrations of 25-hydroxyvitamin $D$ for multiple health outcomes. Am J Clin Nutr 2006;84:18-28.

14. Pearce SH, Cheetham TD. Diagnosis and management of vitamin D deficiency. BMJ 2010;340:b5664.

15. Pludowski P, Holick MF, Pilz S, et al. Vitamin D effects on musculoskeletal health, immunity, autoimmunity, cardiovascular disease, cancer, fertility, pregnancy, dementia and mortality-a review of recent evidence. Autoimmun Rev 2013;12:976-89

16. German Nutrition Society. New reference values for vitamin D. Ann Nutr Metab 2012;60:241-6

17. Lips P. Vitamin D physiology. Prog Biophys Mol Biol 2006;92:4-8.

18. Wang $Y$, Zhu J, Deluca HF. Where is the vitamin D receptor? Arch Biochem Biophys 2012;523:123-33.

19. Meyer $\mathrm{H}$, Nasjonalt råd for ernæring I-. [Proposals to secure a good vitamin D-status in the population] Tiltak for å sikre en god vitamin D-status i befolkningen: rapport fra en arbeidsgruppe nedsatt av Nasjonalt råd for ernæring. Oslo: Nasjonalt råd for ernæring, 2006.

20. Holvik K, Brunvand L, Brustad M, et al. Vitamin D status in the Norwegian population. In: Bjertness E. ed Solar radiation and human health. Oslo: The Norwegian Academy of Science and Letters, 2008:216-28.

21. Knutsen KV, Brekke M, Gjelstad S, et al. Vitamin D status in patients with musculoskeletal pain, fatigue and headache: a cross-sectional descriptive study in a multi-ethnic general practice in Norway. Scand $J$ Prim Health Care 2010;28:166-71.

22. Meyer HE, Falch JA, Sogaard AJ, et al. Vitamin D deficiency and secondary hyperparathyroidism and the association with bone mineral density in persons with Pakistani and Norwegian background living in Oslo, Norway, The Oslo Health Study. Bone 2004;35:412-17.
23. Holvik K, Meyer HE, Haug E, et al. Prevalence and predictors of vitamin $D$ deficiency in five immigrant groups living in Oslo, Norway: the Oslo Immigrant Health Study. Eur J Clin Nutr 2005;59:57-63.

24. Brunvand L, Haug E. Vitamin D deficiency amongst Pakistan women in Oslo. Acta Obstet Gynecol Scand 1993;72:264-8.

25. Meyer HE, Holvik K, Lofthus CM, et al. Vitamin D status in Sri Lankans living in Sri Lanka and Norway. Br J Nutr 2008;99:941-4.

26. Statistics Norway/Population statistics. Secondary Statistics Norway/ Population statistics. http://www.ssb.no

27. Urquia ML, Frank JW, Glazier RH. From places to flows. International secondary migration and birth outcomes. Soc Sci Med 2010;71:1620-6.

28. Fennelly K. The 'healthy migrant' effect. Minn Med 2007;90:51-3.

29. Jafri L, Khan AH, Siddiqui AA, et al. Comparison of high performance liquid chromatography, radio immunoassay and electrochemiluminescence immunoassay for quantification of serum 25 hydroxy vitamin D. Clin Biochem 2011;44:864-8.

30. Tahsin-Swafiri S, Blanco-Navarro I, Perez-Sacristan B, et al. The prevalence of vitamin deficiency in clinical practice is assay-dependent. Clin Nutr 2012;31:1011-14.

31. Iqbal R, Khan AH. Possible causes of vitamin D deficiency (VDD) in Pakistani population residing in Pakistan. J Pak Med Assoc 2010;60:1-2.

32. Sheikh A, Saeed Z, Jafri SA, et al. Vitamin D levels in asymptomatic adults - a population survey in Karachi, Pakistan. PLOS ONE 2012;7:e33452.

33. Manaseki-Holland S, Zulf Mughal M, Bhutta Z, et al. Vitamin D status of socio-economically deprived children in Kabul, Afghanistan Int J Vitam Nutr Res 2008;78:16-20.

34. Islam MZ, Viljakainen HT, Karkkainen MU, et al. Prevalence of vitamin $\mathrm{D}$ deficiency and secondary hyperparathyroidism during winter in pre-menopausal Bangladeshi and Somali immigrant and ethnic Finnish women: associations with forearm bone mineral density. Br J Nutr 2012;107:277-83.

35. Campagna AM, Settgast AM, Walker PF, et al. Effect of country of origin, age, and body mass index on prevalence of vitamin $D$ deficiency in a US immigrant and refugee population. Mayo Clin Proc 2013;88:31-7.

36. http://www.nnr5.org 